\title{
Meta-Analysis the Effect of Residence on the Risk of Anxiety and Depression in General Population during COVID-19 Pandemic
}

\author{
Riyesti Hero Fresna', Bhisma Murti1), Hanung Prasetya ${ }^{2)}$ \\ 1)Masters Program in Public Health, Universitas Sebelas Maret \\ ${ }^{2)}$ Health Polytechnics, Ministry of Health Surakarta
}

Background: The area of residence is one aspect that affects a person's mental health, especially during the COVID-19 pandemic. The difference in the area of residence determines the frequency of exposure to pandemic information in the form of valid invalid information which is increasingly massive, so that between urban and rural areas there can be a potential risk of depression and anxiety. This study aimed to analyze the effect of residence on the risk of anxiety and depression in the population during the COVID-19 pandemic.

Subjects and Method: The meta-analysis was performed by searching for articles from Google Scholar, Pubmed, and ScienceDiret. The keywords used in the article search were "infodemic social media" AND "rural vs urban areas" AND "gender" AND "depression and anxiety" OR "mental health risk". Other keywords used were "COVID-19 information" AND "residence" AND "mental health" OR "depression and anxiety". The inclusion criteria in this study were full-text articles, 2020-2021, with a cross-sectional study design. Article analysis was performed using RevMan 5.3.

Results: There were 12 articles analyzed, the results showed that the effect of living in an urban area had a 1.47 times risk of experiencing mental health problems in the form of anxiety during the COVID-19 pandemic with a statistically significant result of anxiety (aOR=1.47; 95\% $\mathrm{CI}=1.18$ to 1.83) with heterogeneity $\mathrm{I}^{2}=96 \%$. Then, the effect of residence in urban areas has a 1.53 times risk of experiencing mental health problems in the form of depression during the COVID-19 pandemic with a statistically significant result of depression ( $\mathrm{aOR}=1.53 ; 95 \% \mathrm{CI}=1.25$ to 1.86 ) with heterogeneity $\mathrm{I}^{2}=97 \%$.

Conclusion: There is a significant effect of living in an urban area on mental health problems such as anxiety and depression during the COVID-19 pandemic.

Keywords: rural vs urban areas, covid-19, mental health, depression and anxiety, general population

\section{Correspondence:}

Riyesti Hero Fresna, Universitas Sebelas Maret Surakarta, Jl. Ir. Sutami No.36, Kentingan, Jebres, Surakarta 57126, Central Java. Email: riyestiherofresna01@gmail.com. Mobile +6281227831443.

Cite this as:

Fresna RH, Murti B, Prasetya H (2021). Meta-Analysis the Effect of Residence on the Risk of Anxiety and Depression in General Population during COVID-19 Pandemic. J Epidemiol Public Health. 06(03): 381-391. https://doi.org/10.26911/jepublichealth.2021.06.03.12.

Journal of Epidemiology and Public Health is licensed under a Creative Commons

Attribution-NonCommercial-ShareAlike 4.0 International License.

\section{BACKGROUND}

The COVID-19 outbreak has caused various health problems among people in different places of residence, especially in the case of health literacy in the form of infodemic (pandemic information) obtained from social media with great risks related to the validity of information dissemination where this can lead to the risk of experiencing mental health. (Gao et al., 2020). WHO identified the underlying drivers of stress, anxiety and stigma from rumors and invalid information, 
particularly through social media. Previous research has shown that the infodemic from social media exposure can cause mass trauma and increase stress in society. A previous study also showed that the infodemic from social media exposure may influence the formation of risk perceptions during the MERS outbreak in South Korea (Choi et al., 2017).

A recent study showed that nearly $45 \%$ of youth in the US reported an impact on mental health related to psychological problems (Liang et al., 2020). Increased concern about mental health issues was identified as another possible predictor for COVID-19-related fear. During previous pandemics, psychosocial investigations found that morbidity was associated with younger age (Waqas et al., 2020). The pandemic has progressed rapidly and has had an impact on the psychology of society. Previous studies have highlighted the importance of mental and behavioral health screening during a pandemic, which will evaluate the effectiveness of disease prevention. A number of mental health indicators, such as anxiety and worry levels, have been shown to increase during the early stages of the pandemic. Specific health measures are proposed to address, for example, illness-related anxiety or quarantine-related depression (Wenjun et al., 2020).

The disease development research agency is providing the first approach to emotional reactions to the COVID-19 outbreak. Studies from Oxford report that general anxiety has increased in Germany since its inception (Oxford, 2020). The degree of psychological distress is reaching clinical relevance during the COVID-19 pandemic. Xiong et al reported that the general population in China, Spain, Italy, Iran, USA, Turkey, Nepal and Denmark showed high levels of anxiety (6.33\%-
50.9\%), depression (14.6\%-48.3\%), posttrauma (7\%-53.8\%), psychological (34.43\% to $38 \%$ ), and stress $(8.1 \%-81.9 \%)$ (Xiong et al., 2020). Multi-national studies examined the relationship between the prevalence of physical and psychological symptoms (Chew et al., 2020).

Brodin et al. (2020) have shown that people's knowledge and behavior is positively correlated with preventive measures related to COVID-19. Better knowledge and constructive behavior will contribute to controlling the pandemic, as well as controlling aspects that trigger mental health. With this in mind, evaluation of knowledge and behavior will help in slowing the spread of the virus (Brodin., 2020).

Considering the differences in health literacy status between urban (urban) and rural (rural) residents, there is a need to clarify the conditions and differences in knowledge, behavior, and mental health of residents in urban and rural environments so as to promote equity in health literacy. Given the importance of knowledge in controlling COVID-19, it is imperative to examine related factors and explore differences between urban and rural areas, to provide evidence-based public health policies and resource allocation in the hope that findings will provide data support for a sustainable future, relatively stable, and effective during the pandemic, and discuss ways to promote cognition so as to develop targeted measures for the prevention of COVID-19 (Zhang et al., 2021).

Meta-analysis is a statistical method carried out by combining the results of several collected studies, as well as measuring and interpreting the relevant degree of heterogeneity by proposing modifications of the method to apply evidencebased results (Berchilla et al., 2021). This study aimed to analyze the effect of residence on the risk of anxiety and depression 
Fresna et al./ Effect of Residence on the Risk of Anxiety and Depression during COVID-19 Pandemic

in the population during the COVID-19 pandemic.

\section{SUBJECTS AND METHOD}

\section{Study Design}

This study was conducted using a metaanalysis carried out by following the PRISMA flow chart. Meta-analysis was performed by searching articles from electronic databases on Google Scholar, Pubmed, and ScienceDirect. The keywords used in the article search were "infodemic social media" AND "rural vs urban areas" AND "gender" AND "depression and anxiety" OR "mental health risk". Other keywords used were "COVID-19 information" AND "residence" AND "mental health" OR "depression and anxiety".

\section{Inclusion Criteria}

Inclusion criteria for the articles reviewed were full articles published in English and Indonesian, articles reporting the final results of the study with Adjusted Odds Ratio (aOR) and Confidence Interval (CI) 95\% full-text articles with a cross-sectional study design and articles published in 2020-2021.

\section{Exclusion Criteria}

Exclusion criteria for articles that have been previously meta-analyzed, duplicate articles, and research subjects $<100$.

\section{Definition of Operational Variable}

The search for articles was carried out by considering the eligibility criteria defined using the $\mathrm{P}$ (Population) I (Intervention), $\mathrm{C}$ (Comparison), O (Outcome) models. The population in this study is the general population for intervention in residential areas in urban areas by comparing residences in rural areas with the aim of seeing the results between urban areas and rural areas that are at risk of experiencing anxiety and depression during the COVID19 pandemic.

\section{Study Instruments}

This study uses a data collection instrument in the form of a meta-analysis conducted by following PRISMA flow diagrams.

\section{Data Analysis}

The data collection stage in this study was to search for published articles that analyzed the effect of residence on the risk of anxiety and depression during the COVID19 pandemic. The data collection technique in this study consists of identifying articles from reputable journal sites, screening for articles that meet the requirements and conditions according to the criteria set by the researcher so that they are included in the eligibility criteria which will then be analyzed using meta-analysis software which is carried out by following the PRISMA flow. diagrams.

The data analysis process in this study was carried out using RevMan (Review Manager 5.3) to determine the effect size and heterogeneity in this study. The results of data analysis in the meta-analysis are presented in the form of forest plots and funnel plots.

\section{RESULTS}

The search process for articles to be used in this meta-analysis was obtained from electronic databases at Google Scholar, Pubmed, and ScienceDiret. The keywords used in the article search were "infodemic social media" AND "rural vs urban areas" AND "gender" AND "depression and anxiety" OR "mental health risk". Other keywords used were "COVID-19 information" AND "residence" AND "mental health" OR "depression and anxiety". The flow of the article search process can be seen in Figure 1.

There are 12 articles with 4 articles from China, 1 article from the United States, 1 article from the United Kingdom, 1 article from France, 1 article from South Korea, 1 article from Bangladesh, 1 article 
Fresna et al./ Effect of Residence on the Risk of Anxiety and Depression during COVID-19 Pandemic

from India, 1 article from Iran, and 1 article from Ethiopia. The process of searching for articles is carried out by searching through the database according to the PRISMA flow diagram.

From a total of 2,552 articles there were 546 duplicates, articles were filtered to 2,006, 1,967 irrelevant titles, 1,654 irrelevant titles, 273 non-cross-sectional articles,
36 non-full text articles, 36 non-English articles 4, 39 complete and eligible articles, 27 complete articles but excluded with reasons, 10 articles without aOR, 17 articles not relevant to outcome, 12 articles included in the qualitative systematic review, articles included in the study systematic and meta-analysis of 12 .

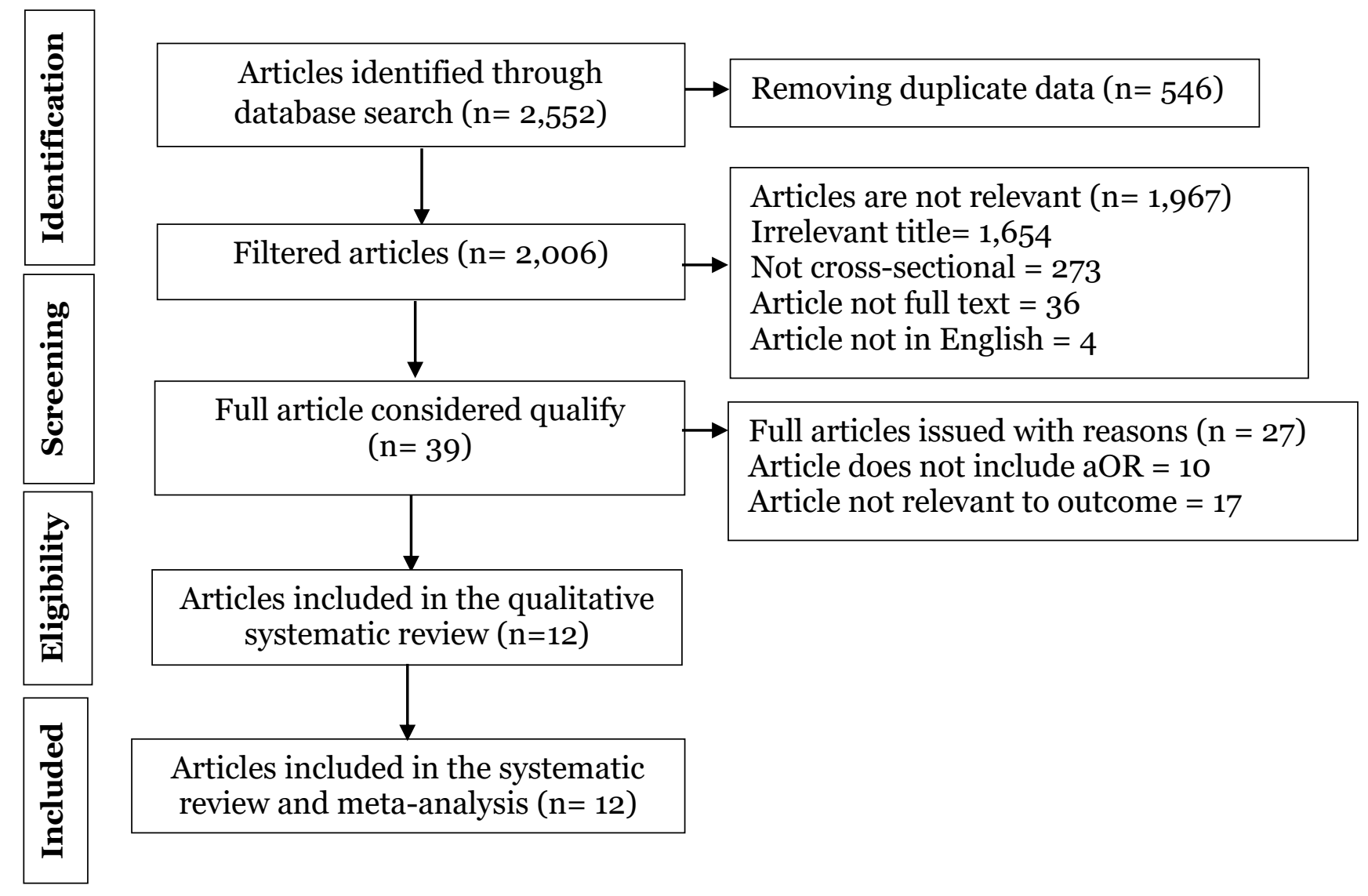

Figure 1. PRISMA flow diagrams The Effect of Residence on the Risk of Anxiety and Depression in the General Population During the COVID-19 Pandemic 
Table 1. Overview of primary studies meta-analyses of the effect of residence on risk of anxiety and depression in the general population during the COVID-19 pandemic

\begin{tabular}{|c|c|c|c|c|c|c|c|}
\hline $\begin{array}{l}\text { Author } \\
\text { (Year) }\end{array}$ & Title & Location & $\begin{array}{l}\text { Study } \\
\text { Design }\end{array}$ & Population & $\begin{array}{c}\text { Inter- } \\
\text { vention }\end{array}$ & $\begin{array}{c}\text { Compa } \\
\text { rison }\end{array}$ & Outcome \\
\hline $\begin{array}{l}\text { Gao } \\
\text { et al. (2020) }\end{array}$ & $\begin{array}{l}\text { Mental health problems and social media } \\
\text { exposure during COVID-19 outbreak }\end{array}$ & China & $\begin{array}{l}\text { Cross- } \\
\text { sectional }\end{array}$ & $\begin{array}{l}\text { 4,827 general } \\
\text { population in China }\end{array}$ & urban & rural & $\begin{array}{l}\text { Anxiety and } \\
\text { Depression Risk }\end{array}$ \\
\hline $\begin{array}{l}\text { Kantor } \\
\text { et al. (2020) }\end{array}$ & $\begin{array}{l}\text { Mental Health Outcomes and Associations } \\
\text { During the COVID-19 Pandemic: A Cross- } \\
\text { Sectional Population-Based Study in the } \\
\text { United States }\end{array}$ & $\begin{array}{l}\text { United } \\
\text { States }\end{array}$ & $\begin{array}{l}\text { Cross- } \\
\text { sectional }\end{array}$ & $\begin{array}{l}\text { 1,005 general } \\
\text { population in } \\
\text { United States }\end{array}$ & urban & rural & $\begin{array}{l}\text { Anxiety and } \\
\text { Depression Risk }\end{array}$ \\
\hline $\begin{array}{l}\text { Wathelet } \\
\text { et al. (2020) }\end{array}$ & $\begin{array}{l}\text { Factors Associated with Mental Health } \\
\text { Disorders Among University Students in } \\
\text { France Confined During the COVID-19 } \\
\text { Pandemic }\end{array}$ & French & $\begin{array}{l}\text { Cross- } \\
\text { sectional }\end{array}$ & $\begin{array}{l}69,054 \text { students in } \\
\text { French }\end{array}$ & urban & rural & $\begin{array}{l}\text { Anxiety and } \\
\text { Depression Risk }\end{array}$ \\
\hline $\begin{array}{l}\text { Sevlin } \\
\text { et al. (2021) }\end{array}$ & $\begin{array}{l}\text { Anxiety, depression, traumatic stress and } \\
\text { COVID-19-related anxiety in the UK general } \\
\text { population during the COVID-19 pandemic }\end{array}$ & $\begin{array}{l}\text { United } \\
\text { Kingdom }\end{array}$ & $\begin{array}{l}\text { Cross- } \\
\text { sectional }\end{array}$ & $\begin{array}{l}2,025 \text { general } \\
\text { population in } \\
\text { United Kingdom }\end{array}$ & urban & rural & $\begin{array}{l}\text { Anxiety and } \\
\text { Depression Risk }\end{array}$ \\
\hline $\begin{array}{l}\text { Lee et al. } \\
(2020)\end{array}$ & $\begin{array}{l}\text { Associations Between COVID-19 } \\
\text { Misinformation Exposure and Belief With } \\
\text { COVID-19 Knowledge and Preventive } \\
\text { Behaviors: Cross-Sectional Online Study }\end{array}$ & $\begin{array}{l}\text { South } \\
\text { Korean }\end{array}$ & $\begin{array}{l}\text { Cross- } \\
\text { sectional }\end{array}$ & $\begin{array}{l}\text { 1,049 general } \\
\text { population in South } \\
\text { Korea }\end{array}$ & urban & rural & $\begin{array}{l}\text { Anxiety and } \\
\text { Depression Risk }\end{array}$ \\
\hline $\begin{array}{l}\text { Khan et al. } \\
(2021)\end{array}$ & $\begin{array}{l}\text { Mental health of young people amidst COVID- } \\
19 \text { pandemic in Bangladesh }\end{array}$ & Bangladesh & $\begin{array}{l}\text { Cross- } \\
\text { sectional }\end{array}$ & $\begin{array}{l}974 \text { general } \\
\text { population in } \\
\text { Bangladesh }\end{array}$ & urban & rural & $\begin{array}{l}\text { Anxiety and } \\
\text { Depression Risk }\end{array}$ \\
\hline $\begin{array}{l}\text { Shukla et al. } \\
(2020)\end{array}$ & $\begin{array}{l}\text { A Moderating Role of Indian Rural and Urban } \\
\text { Environment on the Relationship Between } \\
\text { Various Social Networking Sites and Anxiety } \\
\text { and Depression during Covid-19 }\end{array}$ & India & $\begin{array}{l}\text { Cross- } \\
\text { sectional }\end{array}$ & $\begin{array}{l}691 \text { general } \\
\text { population in India }\end{array}$ & urban & rural & $\begin{array}{l}\text { Anxiety and } \\
\text { Depression Risk }\end{array}$ \\
\hline $\begin{array}{l}\text { Shi et al. } \\
(2020)\end{array}$ & $\begin{array}{l}\text { Prevalence of and Risk Factors Associated } \\
\text { with Mental Health Symptoms Among the } \\
\text { General Population in China During the } \\
\text { Coronavirus Disease 2019 Pandemic }\end{array}$ & China & $\begin{array}{l}\text { Cross- } \\
\text { sectional }\end{array}$ & $\begin{array}{l}56,932 \text { general } \\
\text { population in China }\end{array}$ & urban & rural & $\begin{array}{l}\text { Anxiety and } \\
\text { Depression Risk }\end{array}$ \\
\hline $\begin{array}{l}\text { Wang et al. } \\
(2020)\end{array}$ & $\begin{array}{l}\text { Prevalence of Anxiety and Depression } \\
\text { symptom, and the Demands for Psychological } \\
\text { Knowledge and Interventions in college }\end{array}$ & China & $\begin{array}{l}\text { Cross- } \\
\text { sectional }\end{array}$ & $\begin{array}{l}\text { 44,447 students in } \\
\text { China }\end{array}$ & urban & rural & $\begin{array}{l}\text { Anxiety and } \\
\text { Depression Risk }\end{array}$ \\
\hline
\end{tabular}


Fresna et al./ Effect of Residence on the Risk of Anxiety and Depression during COVID-19 Pandemic

\begin{tabular}{|c|c|c|c|c|c|c|c|}
\hline & $\begin{array}{l}\text { students during COVID-19 epidemic: A large } \\
\text { Cross-Sectional Study }\end{array}$ & & & & & & \\
\hline $\begin{array}{l}\text { Maroufizad } \\
\text { et al. } \\
(2020)\end{array}$ & $\begin{array}{l}\text { Prevalence of Anxiety and Depression in } \\
\text { General Population of Iran during the COVID- } \\
\text { 19 Pandemic: A Web-Based Cross-Sectional } \\
\text { Study }\end{array}$ & Iran & $\begin{array}{l}\text { Cross- } \\
\text { sectional }\end{array}$ & $\begin{array}{l}5,328 \text { general } \\
\text { population in Iran }\end{array}$ & urban & rural & $\begin{array}{l}\text { Anxiety and } \\
\text { Depression Risk }\end{array}$ \\
\hline $\begin{array}{l}\text { Zhang et } \\
\text { al. (2020) }\end{array}$ & $\begin{array}{l}\text { Prevalence of anxiety and depression } \\
\text { symptoms, and association with epidemic- } \\
\text { related factors during the epidemic period of } \\
\text { COVID-19 among 123,768 workers in China: } \\
\text { A large cross-sectional study }\end{array}$ & China & $\begin{array}{l}\text { Cross- } \\
\text { sectional }\end{array}$ & $\begin{array}{l}123,768 \text { workers in } \\
\text { China }\end{array}$ & urban & rural & $\begin{array}{l}\text { Anxiety and } \\
\text { Depression Risk }\end{array}$ \\
\hline $\begin{array}{l}\text { Shifera et } \\
\text { al. (2020) }\end{array}$ & $\begin{array}{l}\text { The Psychological Impacts During the Initial } \\
\text { Phase of the COVID-19 Outbreak, and its } \\
\text { Associated Factors Among Pastoral } \\
\text { Community in West Omo Zone, South-West } \\
\text { Ethiopia, 2020: A Community-Based Study }\end{array}$ & Ethiopia & $\begin{array}{c}\text { Cross- } \\
\text { sectional }\end{array}$ & $\begin{array}{l}845 \text { pastoral } \\
\text { population in } \\
\text { Ethiopia }\end{array}$ & urban & rural & $\begin{array}{l}\text { Anxiety and } \\
\text { Depression Risk }\end{array}$ \\
\hline
\end{tabular}




\section{Forest plot effect of residence on anxiety}

Interpretation of the primary results from the meta-analysis, it was found that the effect of residence in urban areas has a 1.47 times risk of experiencing mental health problems in the form of anxiety during the COVID-19 pandemic with a statistically significant result of anxiety $(\mathrm{aOR}=1.47$; 95\% $\mathrm{CI}=1.18$ to $1.83 ; \mathrm{p}=0.007)$ with heterogeneity $\mathrm{I}^{2}=96 \%$.

\begin{tabular}{|c|c|c|c|c|c|c|c|}
\hline Study or Subgroup & log[Odds Ratio] & SE & Weight & $\begin{array}{c}\text { Odds Ratio } \\
\text { IV, Random, } 95 \% \mathrm{Cl}\end{array}$ & \multicolumn{3}{|c|}{$\begin{array}{c}\text { Odds Ratio } \\
\text { IV, Random, } 95 \% \mathrm{Cl}\end{array}$} \\
\hline Gao 2020 & 0.92 & 0.0816 & $9.7 \%$ & $2.51[2.14,2.94]$ & & $\rightarrow$ & \\
\hline Kantor 2020 & 1.39 & 0.1837 & $8.0 \%$ & $4.01[2.80,5.75]$ & & & \\
\hline Khan 2021 & 0.5188 & 0.3598 & $5.0 \%$ & $1.68[0.83,3.40]$ & & & \\
\hline Lee 2020 & 0.5878 & 0.1901 & $7.9 \%$ & $1.80[1.24,2.61]$ & & $\rightarrow$ & \\
\hline Maroufizadeh 2020 & 0.1823 & 0.1582 & $8.5 \%$ & $1.20[0.88,1.64]$ & & $=-$ & \\
\hline Sevlin 2021 & 0.1823 & 0.182 & $8.1 \%$ & $1.20[0.84,1.71]$ & & & \\
\hline Shi 2020 & 0.4318 & 0.0864 & $9.6 \%$ & $1.54[1.30,1.82]$ & & - & \\
\hline Shifera 2021 & 2.35 & 0.3674 & $4.9 \%$ & $10.49[5.10,21.54]$ & & & \\
\hline Shukla 2020 & -0.755 & 0.1804 & $8.1 \%$ & $0.47[0.33,0.67]$ & 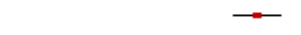 & & \\
\hline Wang 2020 & 0.0198 & 0.0417 & $10.0 \%$ & $1.02[0.94,1.11]$ & & & \\
\hline Wathelet 2020 & 0.01 & 0.0259 & $10.1 \%$ & $1.01[0.96,1.06]$ & & & \\
\hline Zhang 2020 & -0.1744 & 0.0378 & $10.1 \%$ & $0.84[0.78,0.90]$ & $=$ & & \\
\hline \multirow{2}{*}{\multicolumn{5}{|c|}{$\begin{array}{l}\text { Heterogeneity: } \text { Tau }^{2}=0.13 ; \mathrm{Chi}^{2}=294.58, \mathrm{df}=11(\mathrm{P}=0.00001) ; \mathrm{I}^{2}=96 \% \\
\text { Test for overall effect: } Z=3.40(\mathrm{P}=0.0007)\end{array}$}} & & & \\
\hline & & & & & $\begin{array}{l}1 \\
0.1 \\
\text { Rural Area }\end{array}$ & 1 Urban Area & 100 \\
\hline
\end{tabular}

Figure 2. Forest plot effect of residence on anxiety risk in the general population during the COVID-19 pandemic

\section{Funnel plot effect of residence on anxiety}

Interpretation of primary results from meta-analysis, the results show that the effect of living in an urban area on depression shows a publication bias as evidenced by the number of 6 plots on the left and 6 plots on the right, which are not balanced, and the distance between plots is not symmetrical.

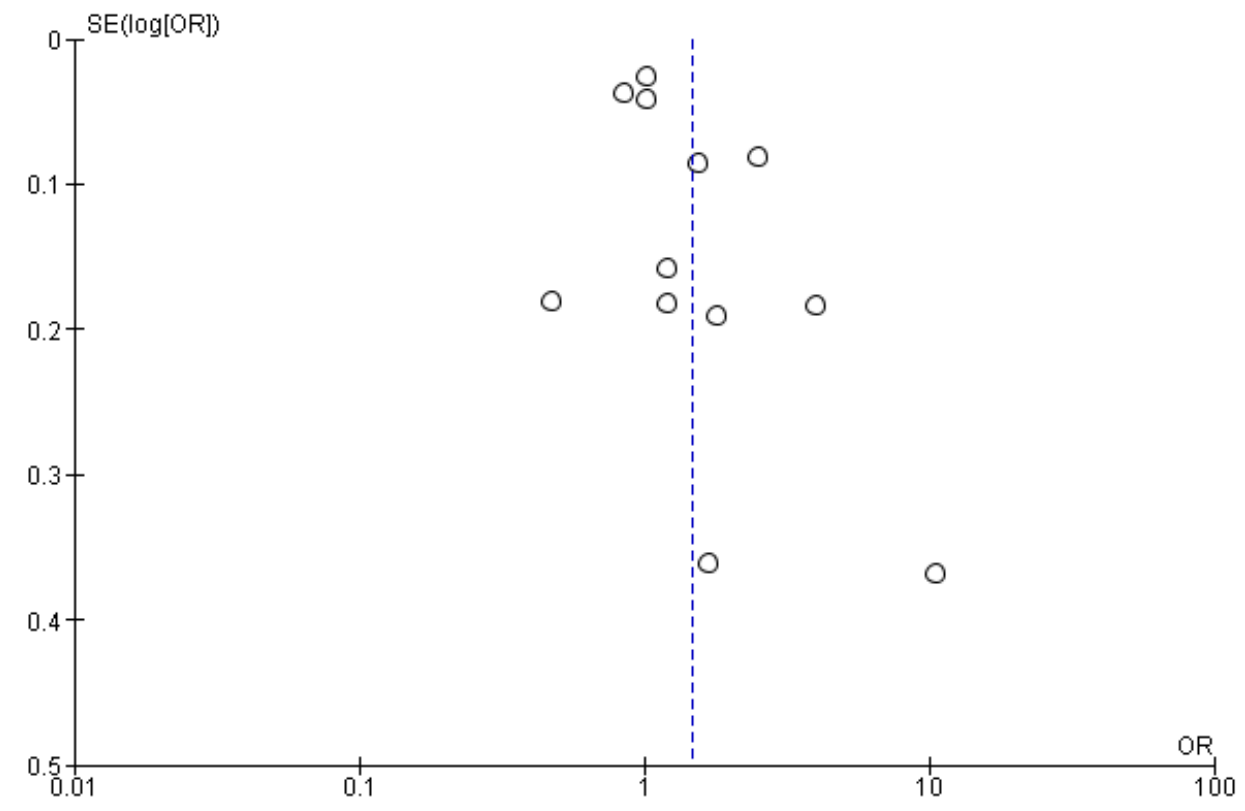

Figure 3. Funnel plot of the effect of residence on anxiety risk in the general population during the COVID-19 pandemic 
Fresna et al./ Effect of Residence on the Risk of Anxiety and Depression during COVID-19 Pandemic

\section{Forest plot effect of residence on depression}

Interpretation of the primary results from the meta-analysis, it was found that the effect of living in an urban area has a 1.53 times risk of experiencing mental health problems in the form of depression during the COVID-19 pandemic with a statistically significant result of depression $(\mathrm{aOR}=1.53 ; 95 \% \mathrm{CI}=1.25$ to $1.86 ; \mathrm{p}<0.001$ ) with heterogeneity $\mathrm{I}^{2}=$ $97 \%$.

\begin{tabular}{|c|c|c|c|c|c|c|c|}
\hline $\begin{array}{l}\text { Study or Subgroup } \\
\text { Gao } 2020\end{array}$ & $\begin{array}{r}\text { log[Odds Ratio] } \\
0.74\end{array}$ & $\begin{array}{r}\mathrm{SE} \\
.051\end{array}$ & $\begin{array}{r}\text { Weight } \\
10.5 \%\end{array}$ & $\begin{array}{c}\text { Odds Ratio } \\
\text { IV, Random, 95\% Cl } \\
2.10[1.90,2.32]\end{array}$ & \multicolumn{3}{|c|}{$\begin{array}{c}\text { Odds Ratio } \\
\text { IV, Random, } 95 \% \mathrm{Cl}\end{array}$} \\
\hline Kantor 2020 & 0.94 & 0.1378 & $9.0 \%$ & $2.56[1.95,3.35]$ & & & $=$ \\
\hline Lee 2020 & 0.3853 & 0.1526 & $8.7 \%$ & $1.47[1.09,1.98]$ & & & $\rightarrow$ \\
\hline Maroufizadeh 2020 & 0.5008 & 0.1499 & $8.7 \%$ & $1.65[1.23,2.21]$ & & & $\rightarrow$ \\
\hline Sevlin 2021 & 0.1906 & 0.1742 & $8.2 \%$ & $1.21[0.86,1.70]$ & & & $t=$ \\
\hline Shi 2020 & 0.3507 & 0.0902 & $9.9 \%$ & $1.42[1.19,1.69]$ & & & - \\
\hline Shukla 2020 & 0.6627 & 0.4092 & $3.9 \%$ & $1.94[0.87,4.33]$ & & & \\
\hline Wang 2020 & -0.0202 & 0.0322 & $10.7 \%$ & $0.98[0.92,1.04]$ & & & \\
\hline Wathelet 2020 & -0.0619 & 0.0279 & $10.7 \%$ & $0.94[0.89,0.99]$ & & & \\
\hline Zhang 2020 & -0.1393 & 0.0179 & $10.7 \%$ & $0.87[0.84,0.90]$ & & - & \\
\hline Total $(95 \% \mathrm{Cl})$ & & & $100.0 \%$ & $1.53[1.25,1.86]$ & & & \\
\hline \multicolumn{5}{|c|}{$\begin{array}{l}\text { Heterogeneity: } \text { Tau }^{2}=0.10 ; \mathrm{Chi}^{2}=398.68, \mathrm{df}=11(\mathrm{P}=0.00001) ; \mathrm{I}^{2}=97 \% \\
\text { Test for overall effect: } Z=4.14(\mathrm{P}=0.0001)\end{array}$} & 0.01 & $\begin{array}{l}1 \\
0.1 \\
\text { Rural Area }\end{array}$ & $\begin{array}{r}10 \\
\text { Urban Area }\end{array}$ \\
\hline
\end{tabular}

Figure 4. Forest plot effect of residence on depression risk in the general population during the COVID-19 pandemic

\section{Funnel plot effect of residence on depression}

Interpretation of the primary results from the meta-analysis, it was found that the effect of living in an urban area on depression showed a publication bias as evidenced by the number of 6 plots on the left and 6 plots on the right being unbalanced, and the distance between plots was not symmetrical.

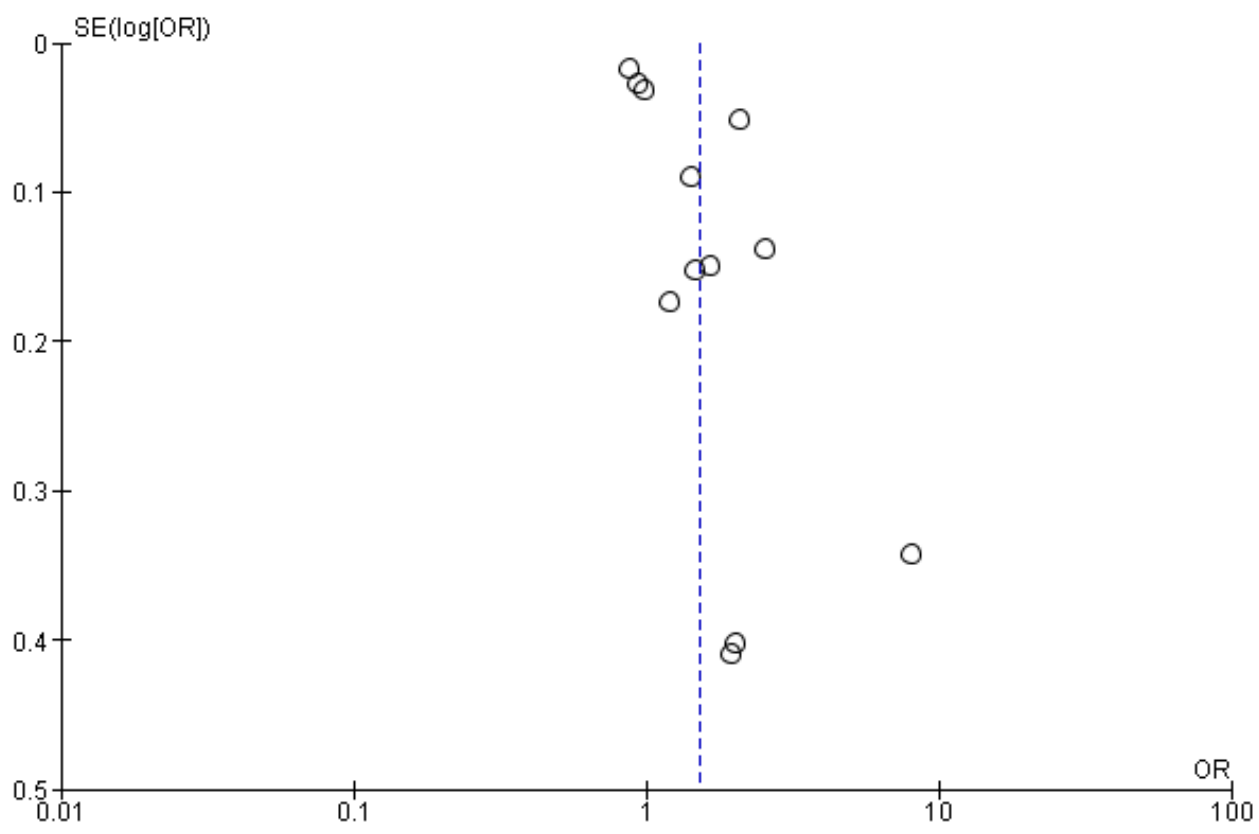

Figure 5. Funnel plot of the effect of residence on depression risk In the general population during the COVID-19 pandemic 
Fresna et al./ Effect of Residence on the Risk of Anxiety and Depression during COVID-19 Pandemic

\section{DISCUSSION}

Place of residence has a major influence on the risk of increasing mental health problems related to the spread of the COVID-19 pandemic. In various countries, control measures have been taken by implementing measures to combat the infodemic by monitoring and filtering out hammer information, as well as promoting accurate information through the collaboration of official services. In China, implementing control measures related to mental health, among others, by providing mental health treatment services including hotlines, online courses, and online consultations (Gao et al., 2020).

This systematic study and metaanalysis raised the topic of the influence of residence on the risk of depression and anxiety during the COVID-19 pandemic. This study is considered important because it strengthens the evidence that predicts and explains the effect of residence on mental health risk in urban and rural areas of residence during the COVID-19 pandemic. The study in this study uses multisectoral collaboration related to controlling the COVID-19 situation, which is a world health problem. This study has controlled the confounding factor which can be seen from the inclusion criteria, namely adjusted odds ratio and 95\% Confidence Interval (CI).

The estimates from this meta-analysis were processed using RevMan 5.3 with the generic inverse variance method to analyze the data in the form of adjusted odds ratio and 95\% Confidence Interval (CI). The estimation results in this study use forest plots and funnel plots. Forest Plot is the amount of variation (heterogeneity) that is presented visually (Murti, 2018). Funnel Plot is the relationship between the magnitude of the study effect and the sample size from various studies that are studied and measured in different ways (Murti, 2018).

\section{The effect of residence on anxiety risk}

The effect of living in an urban area has a 1.47 times risk of experiencing mental health problems in the form of anxiety during the COVID-19 pandemic with statistically significant results $(\mathrm{aOR}=1.47 ; 95 \%$ $\mathrm{CI}=1.18$ to $1.83 ; \mathrm{p}=0.007$ ) with heterogeneity $\mathrm{I}^{2}=96 \%$. These results are supported by WHO (2020) where living in an urban area can significantly affect the risk of anxiety (Khan et al., 2021).

The results of this study are in line with Qiu et al. (2020) which states that urban areas can affect the risk of anxiety and are statistically significant (Shi et al., 2020).

\section{The effect of residence on depression risk}

The results of the meta-analysis in this study showed that living in an urban area had a 1.53 times risk of experiencing mental health problems in the form of depression during the COVID-19 pandemic with statistically significant results $(\mathrm{aOR}=1.53$; 95\% $\mathrm{CI}=1.25$ to 1.86 ; $\mathrm{p}<0.001$ ) with heterogeneity $I^{2}=97 \%$. These results are supported by Xie et al. (2017) which states that living in an urban area can significantly affect the risk of depression (Gao et al., 2020).

This is in line with Son et al. (2020) which states that urban areas can affect the risk of depression statistically significantly (Mekonen et al., 2021).

\section{AUTHORS CONTRIBUTION}

Riyesti Hero Fresna is the main researcher who selects the topic, searches for and collects research data. Hanung Prasetya and Bhisma Murti played a role in analyzing data and reviewing research documents. 
Fresna et al./ Effect of Residence on the Risk of Anxiety and Depression during COVID-19 Pandemic

CONFLICT OF INTEREST

There is no conflict of interest in this study.

FUNDING AND SPONSORSHIP

This study is self-funded.

\section{ACKNOWLEDGMENT}

We are very grateful to the database providers, namely Google Scholar, Pubmed, and ScienceDiret.

\section{REFERENCES}

Arlington VA (2013). Diagnostic and statistical manual of mental disorders. American Psychiatric Association. doi: 10.1016/Bo-12-657410-3/o04578.

Berchialla P, Chiffi D, Valente G, Voutilainen A (2021). The power of metaanalysis: a challenge for evidencebased medicine. Eur J Philos Sci. 11(1): 1-18. doi: 10.1007/s13194-020o0321-w.

Brodin P (2020). Why is COVID-19 so mild in children?. Acta Paediatrica Int J Pediatr. 109(6): 1082-1083. doi: 10.1111/apa.15271.

Cao W, Fang Z, Hou G, Han M, Xu X, Dong J, Zheng J (2020). The psychological impact of the COVID-19 epidemic on college students in China. Psychiatry Res. 287: 112934. 1-5. doi: 10.1016/j.psychres.2020.112934.

Chew NWS, Lee GKH, Tan BYQ, Jing M, Goh Y, Ngiam NJH, Sharma VK (2020). A multinational, multicentre study on the psychological outcomes and associated physical symptoms amongst healthcare workers during COVID-19 outbreak. Brain Behav. Immun. 88(April): 559-565. doi: 10.1016/j.bbi.2020.04.049.

Choi DH, Yoo W, Noh GY, Park K (2017). The impact of social media on risk perceptions during the MERS out- break in South Korea. Comput. Hum. Behav. 72: 422-431. doi: 10.1016/j.chb.2017.03.004.

Clemente SVJ, Navarro JE, Jimenez M, Hormeno HA, Martinez GMB, Benitez AJC, Tornero AJF (2021). Impact of COVID-19 pandemic in public mental health: An extensive narrative review. Sustainability (Switzerland). 13(6). doi: 10.3390/su13063221.

Fidiansjah (2020). Pandemi dan mental health: meringkas isu kesehatan mental selama satu tahun di era pandemi (pandemic and mental health: summarizing mental health issues for one year in the pandemic era). Jurnal Kesehatan. 5(3): 12.

Gao J, Zheng P, Jia Y, Chen H, Mao Y, Chen S, Dai J (2020). Mental health problems and social media exposure during COVID-19 outbreak. PLoS ONE. 15(4) (December 2019), 1-10. doi: 10.1371/journal.pone.0231924.

Khan AS, Debnath S, Islam S, Zaman S, Ambia NE, Barshan AD, Hossain MS, et al. (2021). Mental health of young people amidst COVID-19 pandemic in Bangladesh. Heliyon. 7(6). doi: 10.1016/J.HELIYON.2021.Eo7173.

Kurniawati O, Prasetya H, Murti B (2021). Meta-analysis the effects of obesity and type 2 diabetes mellitus on covid19 mortality. J Epidemiol Public Health. 06(02): 177-191. doi: 10.26911/jepublichealth.2021.06.02.05.

Liang L, Ren H, Cao R, Hu Y, Qin Z, Li C (2020). The Effect of COVID-19 on youth mental health. Psychiatr Q. (1163): 1-12. doi: 10.1007/s11126-020-09744-3.

Mekonen EG, Workneh BS, Ali MS, Muluneh NY (2021). The psychological impact of COVID-19 pandemic on graduating class students at the university of Gondar, Northwest 
Fresna et al./ Effect of Residence on the Risk of Anxiety and Depression during COVID-19 Pandemic

Ethiopia. Psychol Res Behav Manag. 14: 109-122. doi: 10.2147/PRBM.S3O0262.

Murti B (2018). Prinsip dan metode riset epidemiologi (epidemiological research principles and methods). Program Studi Ilmu Kesehatan Masyarakat, Program Pascasarjana, Universitas Sebelas Maret, 5 .

Okan O, Bollweg TM, Berens E, Hurrelmann K, Bauer U, Schae D (2020). Coronavirus-related health literacy: a cross-sectional study in adults during the COVID-19 infodemic in Germany. Int. J. Environ. 17(15): 5503. doi: 10.3390/ijerph17155503.

Oxford (2020). Correspondence not all world leaders use twitter in response to the covid-19 pandemic: impact of the way of angela merkel on psychological distress, behaviour and risk perception. Journal of public health (Oxford, England). 1-3.

Ozma MA, Maroufi P, Khodadadi E, Kose S, Esposito I, Ganbarov K, Kafil HS, et al. (2020). Clinical manifestation, diagnosis, prevention and control of SARS-CoV-2 (COVID-19) during the outbreak period. Infez Med. 28(2): 153-165.

Pool J, Fatehi F, Akhlaghpour S (2021). Infodemic, misinformation and disinformation in pandemics: scientific landscape and the road ahead for public health informatics research. Online J. Public Health Inform. 281: 764-768. doi: 10.3233/SHTI210278.

Rothan HA, Byrareddy SN (2020). The epidemiology and pathogenesis of coronavirus disease (COVID-19) outbreak. J Autoimmun. 109:102433. doi: 10.1016/j.jaut.2020.102433.

Shi L, Lu Z-A, Que JY, Huang X-L, Liu L, Ran M-S, Gong Y-M, et al. (2020). Prevalence of and risk factors asso- ciated with mental health symptoms among the general population in China during the coronavirus disease 2019 pandemic. JAMA Netw Open. 3(7): e2014053. doi: 10.1001/jamanetworkopen.2020.14053.

Stats NZ (2021). Functional urban areas methodology and classification. Stats NZ - Methods. 1-29. https://www.stats.govt.nz/methods/functional-urban-areas-methodology-and-classification.

Waqas M, Hania A, Hongbo L (2020). Psychological predictors of anxious responses to the covid-19 pandemic: Evidence from pakistan. Psychiatry Investig. 17(11): 1096-1104. doi: 10.30773/pi.2020.0167.

Willyard KA, Branch SAE (2021). Ruralurban differences in community resilience to COVID-19 in the United States Abstract. Paper Knowledge. Toward a Media History of Documents 1-13.

Xiong J, Lipsitz O, Nasri F, Lui LMW, Gill $\mathrm{H}$, Phan L (2020). Impact of COVID19 pandemic on mental health in the general population: A systematic review. J Affect Disord. 277: 55-64. doi: 10.1016/j.jad.2020.08.001.

Zhang J, Zhu L, Li S, Huang J, Ye Z, Wei Q, Du C (2021). Rural-urban disparities in knowledge, behaviors, and mental health during COVID-19 pandemic: A community-based cross-sectional survey. Medicine (Baltimore). 100 (13): e25207. doi: 10.1097/MD.o000000000025207. 